\title{
THE INFLUENCE OF IMF PROGRAMS ON THE RE-ELECTION OF DEBTOR GOVERNMENTS
}

\author{
AXEL DREHER*
}

\begin{abstract}
The paper develops a model explaining why IMF programs are less likely to be concluded before national election dates. Since conclusion of an IMF arrangement may signal the incumbent's incompetence, rational voters use this signal when deciding upon his re-election. In order to demonstrate competence, politicians may therefore decide not to conclude IMF programs prior to elections. The model also shows that re-election probabilities of politicians who nevertheless conclude arrangements at election times depend on the state of the economy. Using panel data for 96 countries between 1976 and 1997, the model is tested empirically. The results show that conclusion of an IMF arrangement within six months prior to an election increases re-election probabilities when GDP growth is low, but reduces the chance to win an election with high growth rates.
\end{abstract}

\section{INTRODUCTION}

IN ORDER to increase their re-election chances governments often try to stimulate their economy at election time (e.g. Schuknecht, 2000). Recently, Dreher and Vaubel (2004) have shown that in this context IMF loans might be important. This is because governments can use the money paid out by the Fund directly for election purposes - at least if conditionality does not prevent an abuse (Vaubel, 1991). Moreover, an overvalued exchange rate generated by fiscal expansion prior to elections can be maintained with the money.

Political costs to negotiate or maintain IMF programs might be, however, particularly high prior to elections. Dreher (2003a, 2003b) provides empirical evidence. He shows that the likelihood of program conclusion is significantly lower within six months prior to elections. Moreover, IMF programs seem to be more likely to break down before elections. According to Vreeland (1999, p. 8), governments might generally be less willing to conclude arrangements at this time. A similar point has been made by Bird and Rowlands (2000, p. 7):

Referral to the IMF is seen as a sign of severe economic distress. ... Where an incumbent government is better able to blame a predecessor, it may be more

\footnotetext{
*University of Mannheim, Lehrstuhl für Volkswirtschaftslehre, L7, 3-5, 68131 Mannheim, Germany. E-mail: mail@axel-dreher.de
} 
prepared to involve the Fund. The ability to blame the preceding government will in turn be a decreasing function of the length of time that the current government has been in power.

It seems that most governments fear losing upcoming elections after accepting Fund conditionality immediately prior to them. This could be because politicians and their electorate have different expectations regarding the effects of the program. Whereas voters expect a worsening of their personal situation, governments expect benefits from the arrangement to prevail. These different expectations on the results of IMF programs might emerge because politicians as well as some groups protected by them derive benefits from IMF money or conditions attached to it although the population as a whole is worse off (Vreeland, 2002). As another explanation, voters might be more shortsighted than are politicians. During the adjustment period the economy might on average perform worse. In the longer run, however, the government and the IMF probably expect their policies to improve the situation. ${ }^{1}$ These different expectations - and fears of losing office - could make politicians defer adjustment measures and IMF programs until after the election.

According to case study evidence reported by Killick (1995), however, IMF programs helped maintain governments in office in the majority of the cases examined. This could result from a boom supported by IMF money. In that case, support gained with the help of Fund credit would outweigh the loss of support due to program conclusion. Nelson (1992) provides additional evidence contradicting the above explanation:

Despite the fact that incumbent governments are likely to delay reforms prior to elections, it does not appear to be the case that governments that have undertaken adjustment programs will necessarily suffer for it electorally.

Thus there is a puzzle: governments appear to avoid IMF programs before elections, yet governments that enter into programs appear to win elections. If entering an IMF program hurts electoral prospects, why do governments that enter into programs win re-elections? If IMF programs increase the chances of re-election, why do so few countries participate in them before elections? My argument follows Collier (1997, p. 60) who indicates that conditions associated with IMF credit could signal the incumbents' incompetence. Based on that consideration, the next three sections develop a formal model that can explain the stylized facts. Basically, competent governments signal

\footnotetext{
${ }^{1}$ However, empirical evidence on the results of IMF involvement is mixed. For example, Killick et al. (1992), Schadler et al. (1993), and Dicks-Mireaux et al. (2000) found a positive correlation between IMF programs and growth, while Przeworski and Vreeland (2000) and Barro and Lee (2001) report a negative influence. Boockmann and Dreher (2003) did not find a significant correlation between IMF involvement in a country and its degree of economic freedom.
} 
their competence in election years by not concluding IMF programs when a certain state of the economy prevails. This induces voters to re-elect competent incumbents, whereas incompetent ones lose the election.

Section 5 presents an extension to the basic model. The empirical test for the model can be found in section 6 . Finally, section 7 sums up and draws conclusions for IMF reform.

\section{THE MODEL}

Consider a country which is run by elected politicians, who are potentially of two kinds: "competent" or "incompetent." The population elects the chief executive directly at the end of every second period. Two candidates compete for the job: the incumbent and an opponent chosen randomly from the population. Like the incumbent, and with the same probability, the opponent can either be competent or incompetent. Let the probability of choosing an opponent who is competent be $\alpha$; an incompetent opponent is chosen with probability $(1-\alpha)$, where $\alpha$ is between zero and one. A politician's competence is not constant over time and is distributed over different periods independently from the past. Incumbents who are incompetent during their first term could thus increase their competence. On the other hand, initially competent politicians could lose their competence during their term of office. ${ }^{2}$ Utility of the (identical) voters is given by:

$$
U_{t}^{V}=F\left(c_{t}, c_{t+1}^{e, V}\right),
$$

where current economic performance is denoted by $c_{t}$ and $c_{t+1}^{e, V}$ is the economic situation expected by the voters for the next period. Each period's economic climate depends on the chief executive's competence $K$, which can be high $\left(K^{h}\right)$ or low $\left(K^{l}\right)$. Moreover, a negative shock $Q$ realizes in each period which affects the current state of the economy. ${ }^{3}$ The extent of the shock can either be high $\left(Q^{h}\right)$, medium $\left(Q^{m}\right)$, or low $\left(Q^{l}\right)$. Voters do not know which type of shock hit their economy. However, they form expectations about the probabilities associated with each shock $\left(q^{h}, q^{m}, q^{l}\right)$.

The government immediately realizes the type of shock. ${ }^{4}$ In order to reduce the negative consequences of the shock on economic performance,

\footnotetext{
${ }^{2}$ Competence could depend, e.g., on important advisers. If those advisers are replaced, a politician's competence is probably influenced. Persson and Tabellini (2000, p. 86) justify changing competence over time with changes in tasks to be solved by the politicians. Politicians who can solve certain tasks might be completely incompetent in solving other types of problems. Alternatively, one could assume - and this is probably close to reality - that voters forget signals of competence over time. The solution would be the closer to the one derived here, the higher the weight of periods close to the election.

${ }^{3}$ If positive shocks are also considered, the results of this analysis are unchanged.

${ }^{4} \mathrm{~A}$ similar approach is used by Besley and Case (1995). In their model, rational voters use the level of taxation to infer the (unknown) competence type of the incumbent. If the probability of greater shocks is sufficiently high, voters re-elect "bad" politicians who mimic the policies of "good" politicians.
} 
TAble 1 ECONOmic Performance

\begin{tabular}{lccc}
\hline & Low shock & Medium shock & High shock \\
\hline Incompetent incumbent & $c_{3}$ & $c_{2}$ & $c_{1}$ \\
Competent incumbent & $c_{4}$ & $c_{3}$ & $c_{2}$ \\
\hline
\end{tabular}

foreign credit is needed if the economy performs worse than $c_{4}$. Provided the government is able to raise these loans, economic performance depends on the magnitude of the shock and the incumbents' competence. One of four different states of the economy is achieved, with 1 being the worst state and 4 being the best (see Table 1).

Loans could either be provided by the IMF or on a bilateral basis (by other countries or the international capital market). They are disbursed during period $t$. Voters are informed immediately on the conclusion of a credit arrangement. They also know the situation which arises depending on the shock and the incumbent's competence and can observe current economic performance.

The Fund mainly lends to incompetent governments (adverse selection), since politicians who are unwilling or unable to reform are less creditworthy in the private market and have to go to the IMF more often (Vaubel, 1991; Ergin, 1999). I assume that private creditors and other countries do not lend to incompetent governments at all, whereas the Fund is willing to lend to them as well - as long as it expects the implementation of its conditions. This is because countries rarely default on the IMF and, as a consequence, competence is not important for the Fund.

Since incumbents are chosen directly from the population, part of their utility function is identical to those of the voters. Moreover, the incumbent derives utility from having the possibility to pursue his political targets, i.e. from being in office. ${ }^{5}$ While money from the Fund is highly subsidized for most borrowers, it is associated with conditionality. Since IMF conditionality reduces the politicians' leeway in $t$, his utility is lower, the more stringent those conditions. On the other hand, the interest rate subsidy provided by the IMF increases his leeway and thus his utility. Utility of the incumbent is given by:

$$
U_{t}^{I}=F\left(c_{t}^{e, I}, c_{t+1}^{e, I}\right)+I_{t}^{e}\left(p_{t}\right)+\eta\left(p_{t}\right) I_{t+1}^{e}\left(p_{t+1}^{e}\right) .
$$

${ }^{5}$ If the population is sufficiently large, this component can be neglected in the voter's utility function, since the probability of getting elected approaches zero. Rogoff (1990) employs a similar structure to explain higher consumption in election years: identical voters derive utility from (private) consumption and investment goods as well as from a public consumption good. The incumbent derives additional utility from holding office. 
The politician expects a certain state of the economy $c^{e, I}$ in each period. $I^{e}$ is the utility derived from the expectation of being in office, $p$ is one if an IMF arrangement has been concluded and zero otherwise. Expected utility from holding office directly depends on the conclusion of an IMF program. Theoretically, this relationship could be positive as well as negative. It is positive if the increased leeway due to subsidized IMF loans exceeds the costs of conditionality, and negative if the effect of conditionality prevails. The probability of holding office in $t+1$ is denoted by $\eta$. This probability is influenced by program conclusions as well.

This period's economic performance expected by the incumbent depends directly on his competence, the (already realized) shock and the expected amount of loans $D_{t}^{e}$ (which again depends on the politicians' competence):

$$
c_{t}^{e, I}=g\left(K_{t}, Q_{t}, D_{t}^{e}\left(K_{t}\right)\right) .
$$

Expectations about next period's economic performance are built analogously.

\section{THE MODEL WITH COMPLETE INFORMATION ABOUT COMPETENCE}

The following equations refer to election periods. The results are the same in non-election periods, however, since the politicians' decisions do not influence electoral outcomes. If the incumbent's competence is known, the competent politician is always re-elected $(\eta=1)$, while the incompetent one never wins $(\eta=0){ }^{6}$

At the beginning of period $t$ the incumbent has to decide whether or not to negotiate an IMF arrangement. He faces a tradeoff between the interest rate subsidy and conditionality.

The incompetent incumbent maximizes:

$$
\begin{aligned}
U_{t}^{I}= & F\left(c_{t}^{e, I}\left(K_{t}^{l}, Q_{t}, D_{t}^{e}\left(K_{t}^{l}\right)\right), c_{t+1}^{e, I}\left(K_{t+1}^{e}, Q_{t+1}^{e}, D_{t+1}^{e}\left(K_{t+1}^{e}\right)\right)\right) \\
& +I_{t}^{e}\left(p_{t}\right) .
\end{aligned}
$$

The politicians' utility depends on economic performance, and economic performance is influenced by loans. Incompetent officials cannot get loans on a bilateral basis, however. After (negative) shocks, therefore, they try to negotiate an IMF arrangement as long as the increase in utility due to an improvement in economic performance outweighs a potentially negative direct effect of the program. If the economy is in really bad shape, the politicians' incompetence is observable. This is because an economic performance of $c_{1}$ can only be due to incompetence. The IMF can thus justify its lending only if the government credibly promises to comply with

${ }^{6}$ Surely, (economic) policies, money spent on campaigning, regional and ethnic affiliations, and charisma, among others, also influence electoral prospects. The model does not explicitly account for those effects. Some of them will, however, be allowed for in the empirical analysis. Others are not quantifiable and can therefore not be included. 
tough conditionality. ${ }^{7}$ I therefore assume that after high shocks the net effect of a program on the incumbent's utility is negative. The politician prefers bad economic performance over the Fund's conditions. With small and medium shocks the Fund's conditionality is softer, and the net utility of its program is therefore positive.

Competent officials maximize:

$$
\begin{aligned}
U_{t}^{I}= & F\left(c_{t}^{e, I}\left(K_{t}^{h}, Q_{t}, D_{t}^{e}\left(K_{t}^{h}\right)\right), c_{t+1}^{e}\left(K_{t+1}^{h}, Q_{t+1}^{e}, D_{t+1}^{e}\left(K_{t+1}^{h}\right)\right)\right) \\
& +I_{t}^{e}\left(p_{t}\right)+I_{t+1}^{e}\left(p_{t+1}^{e}\right) .
\end{aligned}
$$

Since the politicians' competence is known, his behavior does not influence his (certain) re-election. I assume that competent politicians could attract bilateral credits sufficient to finance the effects of medium shocks. After those shocks they can, therefore, choose whether to borrow from the market or the IMF. Thus, the tradeoff between the loss in utility due to conditionality and the increase in utility due to subsidized loans is critical for the decision to negotiate an arrangement. During program negotiations Fund staff come into contact with high-level government representatives. The Fund is thus able to identify the government's competence and demands only moderate reforms. For the following analysis I therefore assume that after medium shocks the net direct utility derived from the program is positive for competent incumbents. With high shocks, competent politicians have no alternative to the Fund; with low shocks, they do not need loans at all.

If politicians have no influence on their re-election probability, the decision to turn to the Fund is independent from election dates: incompetent politicians negotiate an arrangement with low and medium shocks, since after high shocks the net effect of a program on the incumbent's utility is negative. Competent politicians turn to the Fund with medium and high shocks. They do not need loans after low shocks (and cannot further improve economic performance) ${ }^{8}$

The following section examines the behavior of voters and politicians if they do not know the incumbent's competence.

\section{THE MODEL UNDER IMPERFECT INFORMATION ABOUT COMPETENCE}

If the incumbent's competence is not known, rational voters use available information to identify this competence. Only competent politicians have access to bilateral loans. With some states of the economy, they could

\footnotetext{
${ }^{7}$ The IMF often disburses its loans to governments even if it is obvious that they are not inclined to reform. In times of severe crisis, however, the Fund only lends if governments credibly promise sweeping reforms, otherwise the Fund suspends its loans (as has been the case in Argentina since 1999). A more complete analysis of the determinants of IMF conditionality is given in Dreher (2003c).

${ }^{8}$ This could be, e.g., because domestic savings are sufficient to absorb the effects of a small shock.
} 
therefore choose to signal their competence by borrowing from the market or other countries instead of concluding an IMF arrangement. As signals from past periods, however, do not influence re-election probabilities, in non-election periods all politicians behave exactly the same as in the case of complete information about their competence. As the following considerations show, however, this is not true in election years. ${ }^{9}$

With states of the economy $c_{1}$ (or worse) ${ }^{10}$ and $c_{4}$ at the end of $t$ voters directly identify the incumbent's competence. Competent incumbents get reelected, incompetent ones lose the election. If the state of the economy is $c_{2}$, both competent and incompetent incumbents conclude an IMF arrangement. Competent politicians face only loose conditionality, so they derive a positive net direct effect of a program. Incompetent ones probably have to accept harder conditions. Nevertheless, with medium shocks the (expected) overall effect of the IMF on (expected) economic performance and (expected) utility from holding office is assumed to be positive.

Voters observing an economic climate $c_{2}$ and conclusion of a program, utilize this information to update their beliefs about the incumbent's competence. Bayes' theorem provides a way to calculate these "degree of belief" adjustments:

$$
\frac{\alpha \cdot q^{h}}{\alpha \cdot q^{h}+(1-\alpha) \cdot q^{m}} \text {. }
$$

This probability of having a competent incumbent in office is greater than $\alpha$ if voters expect higher shocks with a higher probability than lower ones $\left(q^{h}>q^{m}\right) .{ }^{11}$ In this case politicians get re-elected, even though they conclude a program. ${ }^{12}$

With a perceived economic climate $c_{3}$, both competent and incompetent politicians would conclude a program in non-election years. In election years, however, the incumbent's decision whether or not to turn to the Fund can influence his re-election probability. Whether the conditional probability

$$
\frac{\alpha \cdot q^{m}}{\alpha \cdot q^{m}+(1-\alpha) \cdot q^{l}}
$$

of having a competent incumbent in office is greater than the probability of drawing a competent person from the population again depends on voters'

\footnotetext{
${ }^{9}$ If competence would be constant over time, politicians would act identically in election and non-election periods - otherwise voters would employ signals on competence received in the non-election period when deciding whether to re-elect the incumbent.

${ }^{10}$ Since incompetent politicians do not borrow at all if the shock is high, economic performance at the end of $t$ is actually worse than $c_{1}$.

${ }^{11}$ Governments thinking about the conclusion of an IMF program probably face high shocks, so this assumption seems reasonable.

${ }^{12}$ To derive this result, it is not necessary that voters know the true $\alpha$. Alternatively, $\alpha$ could be the share of potentially competent people expected by these voters.
} 
TABle 2 Do Governments CONClude AN IMF ARRANGEMENT?

\begin{tabular}{|c|c|c|c|c|}
\hline \multirow[b]{2}{*}{$\begin{array}{l}\text { Economic } \\
\text { performance }\end{array}$} & \multicolumn{2}{|c|}{ Competent incumbent } & \multicolumn{2}{|c|}{ Incompetent incumbent } \\
\hline & $\begin{array}{l}\text { Non-election } \\
\text { year/complete } \\
\text { information }\end{array}$ & Election year & $\begin{array}{l}\text { Non-election } \\
\text { year/complete } \\
\text { information }\end{array}$ & Election year \\
\hline$c_{4}$ & No (not necessary) & No (not necessary) & 1 & 1 \\
\hline$c_{3}$ & $\begin{array}{l}\text { Yes (better than } \\
\text { private credit) }\end{array}$ & $\begin{array}{l}\text { No (private credit to } \\
\text { show competence) }\end{array}$ & $\begin{array}{l}\text { Yes (no private } \\
\text { money available) }\end{array}$ & $\begin{array}{c}\text { Yes (no private } \\
\text { money available) }\end{array}$ \\
\hline$c_{2}$ & $\begin{array}{l}\text { Yes (private loans } \\
\text { insufficient) }\end{array}$ & $\begin{array}{l}\text { Yes (private loans } \\
\text { insufficient) }\end{array}$ & $\begin{array}{c}\text { Yes (no private } \\
\text { money available) }\end{array}$ & $\begin{array}{l}\text { Yes (no private } \\
\text { money available) }\end{array}$ \\
\hline$c_{1}^{*}$ & 1 & 1 & $\begin{array}{c}\text { No (tough } \\
\text { conditionality) }\end{array}$ & $\begin{array}{l}\text { No (tough } \\
\text { conditionality) }\end{array}$ \\
\hline
\end{tabular}

*Since incompetent governments do not borrow at all with high shocks, economic performance is actually worse than $c_{1}$.

expectations about the shock. Without additional information, voters reelect their incumbent if they expect medium shocks with a higher probability than low shocks $\left(q^{m}>q^{l}\right)$. Voters know, however, that the competent official could signal his competence by not turning to the Fund. If we assume that losing office is prohibitive, ${ }^{13}$ and voters know it is prohibitive, they expect competent politicians to signal their competence by overcoming the crisis without the IMF. Program conclusion thus directly affects voters' expectations about competence. Therefore, after concluding an arrangement, incumbents lose the election and, as a consequence, the utility they could derive from a second term in office. This induces competent politicians to signal their competence by not asking for Fund assistance. The competent incumbent wins the election, the incompetent one gets no private loans and loses the election. The results are summarized in Table 2 .

The model thus explains two things. First, prior to elections fewer programs are concluded than otherwise. This is because under certain assumptions incumbents can signal their competence by not concluding arrangements. The model therefore is in line with the empirical results of Dreher (2003b). Second, conclusion of an IMF program prior to elections does not necessarily decrease the incumbent's re-election chances. When the economy performs badly, incumbents win the election even though they conclude an arrangement. Only if the economy performs well, does the conclusion of an IMF program signal the incumbent's incompetence. The opponent then wins the election.

The second part of the model can be tested empirically as well. While this empirical question will be examined later, the next section continues with an extension of the basic model.

\footnotetext{
${ }^{13}$ This assumption also guarantees that no incumbent leaves office voluntarily to increase next period's expected economic performance.
} 


\section{AN EXTENSION: THE MODEL WITH GLOBAL SHOCKS}

This section analyzes shocks affecting more than one country in the same fashion. It is assumed that voters can observe whether neighboring countries have concluded IMF arrangements. Again, politicians know the exact extent of the shock, whereas voters only form probabilities about their occurrence.

As in the previous section, voters observe their own country's economic performance and - additionally - the performance of one neighbor ("benchmark") country. Depending on the relative performance of the two economies and their re-election probability politicians again decide upon whether to conclude an IMF arrangement. Voters observe this decision and economic performance at the time they decide whether to reelect the incumbent. Table 3 presents the possible combinations in country A of election results and program conclusions depending on economic outcomes in both country A and B.

Most of the results are obvious. Since the shocks in both countries are identical, voters know the competence of their incumbent if one economy performs better than the other. As a consequence, the competent politician wins the election whereas the incompetent one is replaced. Therefore, incumbents turn to the IMF according to their preferences, i.e. competent politicians conclude an IMF arrangement with medium and high shocks, incompetent politicians with small and medium ones. If voters observe the same performance in both countries, the conditional probability that the incumbent is competent can again be determined using Bayes' theorem.

If the state of the economy in both countries is $c_{3}$, with known competence politicians of both types conclude arrangements. Again, if medium shocks were more likely than low ones without additional information both competent and incompetent officials would conclude IMF arrangements, since in this case

$$
\frac{\alpha^{2} \cdot q^{m}}{\alpha^{2} \cdot q^{m}+(1-\alpha)^{2} \cdot q^{l}}
$$

TABle 3 CONCLUSION OF IMF PROGRAMS WITH BENCHMARKING

\begin{tabular}{|c|c|c|c|c|}
\hline \multirow[b]{2}{*}{ Country A } & \multicolumn{4}{|c|}{ Country B (“benchmark country”) } \\
\hline & $c_{1}^{*}$ & $c_{2}$ & $c_{3}$ & $c_{4}$ \\
\hline$c_{1}{ }^{*}$ & $\begin{array}{l}\text { Not re-elected, } \\
\text { no IMF }\end{array}$ & $\begin{array}{l}\text { Not re-elected, } \\
\text { no IMF }\end{array}$ & l & 1 \\
\hline$c_{2}$ & Re-elected, IMF & Re-elected, IMF & Defeat, IMF & 1 \\
\hline$c_{3}$ & 1 & Re-elected, IMF & Depends on type & Defeat, IMF \\
\hline$c_{4}$ & 1 & 1 & Re-elected, no loans & Re-elected, no loans \\
\hline
\end{tabular}

*Since incompetent governments do not borrow at all with high shocks, economic performance is actually worse than $c_{1}$. 
would be greater than $\alpha$. Compared to the previous section this condition would be less stringent because politicians would also get re-elected if $q^{m}>1-\alpha$. As in the previous section, however, competent politicians could signal their competence if they would not borrow from the IMF. Since rational voters expect their (rational) incumbent to give that signal, politicians can only win the election by not turning to the Fund. Competent politicians get re-elected; incompetent ones lose the election (and negotiate a Fund agreement).

An economic performance $c_{2}$ in both countries can derive from incompetent politicians and medium shocks as well as from competent incumbents and high shocks. As was the case in the previous section, politicians who conclude an IMF arrangement win the election if voters expect high shocks with greater probabilities than medium shocks. Independent of the relative probability of the shocks, incumbents win the election if $q^{h}>1-\alpha$, since in this case, the (on $c_{2}$ ) conditioned probability

$$
\frac{\alpha^{2} \cdot q^{h}}{\alpha^{2} \cdot q^{h}+(1-\alpha)^{2} \cdot q^{m}}
$$

that politicians in both countries are competent is greater than $\alpha$. Therefore, the incumbents' re-election probability rises if high shocks and good politicians are more likely. ${ }^{14}$ This condition is less stringent compared to the case without a benchmark country. As was the case without a benchmark, politicians of both types conclude IMF arrangements.

If voters can compare the outcomes in their own economy with a benchmark country the results range between those obtained in non-election years and those with unknown competence without a benchmark. Compared to the result without a benchmark, incompetent politicians can be identified more often with the result that they lose the election (with economic performance $c_{2}$ in the considered country and $c_{3}$ in the benchmark country). Moreover, IMF programs are concluded more frequently (with performance $c_{3}$ in the considered country and $c_{2}$ in the benchmark country). Still, fewer programs are concluded in election years compared to nonelection years (with $c_{3}$ and competent politicians in both countries).

Whether the relative performance of countries located in a certain region influences re-election chances will be part of the following empirical section.

\section{EMPIRICAL TEST}

This section tests whether incumbents who have concluded IMF programs on average get more frequently re-elected than not. I also examine whether the effect of program conclusions on election outcomes depends on

\footnotetext{
${ }^{14}$ Exactly, incumbents win the election if $\alpha$ is at least 0.58 and $q_{h}>q_{m}+q_{l}$ and $q_{m}>q_{l}$ and lose them otherwise.
} 
economic growth and whether economic performance relative to other countries has an impact.

The regression is a pooled time-series cross-section analysis (panel data). The annual data cover the years 1976-1997 and extend to 96 developing countries that have obtained IMF credit during this period. Some of the data are not available for all countries or years. Therefore the panel data are unbalanced and the number of observations depends on the choice of explanatory variables. Since the dependent variable is binary, a probit (random effects) model is employed. The countries included in the analysis as well as all variables, their precise definitions, summary statistics, and data sources are listed in the Appendix.

The dependent variable is a dummy taking the value of one if, in a national election, the party of the incumbent loses and zero otherwise. The data cover 367 (executive and legislative) election years. Column 1 of Table 4 regresses this dummy on five macroeconomic variables (all lagged one year) accounting for the state of the economy:

- the growth rate of real GDP;

- general government consumption relative to GDP;

- the current account balance relative to GDP;

- the rate of inflation;

- the share of foreign short-term debt in total foreign debt.

All variables probably influence voters' perceptions of the economic climate and are therefore likely to influence their election decision. ${ }^{15}$ However, only real GDP growth rates are significantly correlated with re-election prospects. As expected, higher growth rates lead to a higher re-election probability. In order to increase the incumbent's re-election chances monetary and fiscal policies are usually more expansive prior to elections. As column 2 shows, however, these policies do not seem to be successful. ${ }^{16}$

Column 3 tests for the influence of political variables: if politicians held office for a long time, voters might be better informed about their competence. If they have already been re-elected, the probability of another re-election could therefore rise (which would contradict the assumption made about competence in the theoretical part). On the other hand, voters could be tired of the acting politicians and therefore vote them out of office.

If the government consists of several parties, the probability should be higher that the winner of the election is not from the incumbent's party.

\footnotetext{
${ }^{15}$ I employ GDP growth rates instead of growth rates per capita since the former receive more attention and are more widely known to voters. Anyway, correlation between the two measures is 0.95 .

${ }^{16}$ The insignificant coefficients of these variables suggest that the increased re-election probability after conclusion of an IMF program does not result from expansionary policies financed with IMF money. I also included the amount of Fund credit drawn (in percent of GDP). Its coefficient is insignificant as well.
} 
64

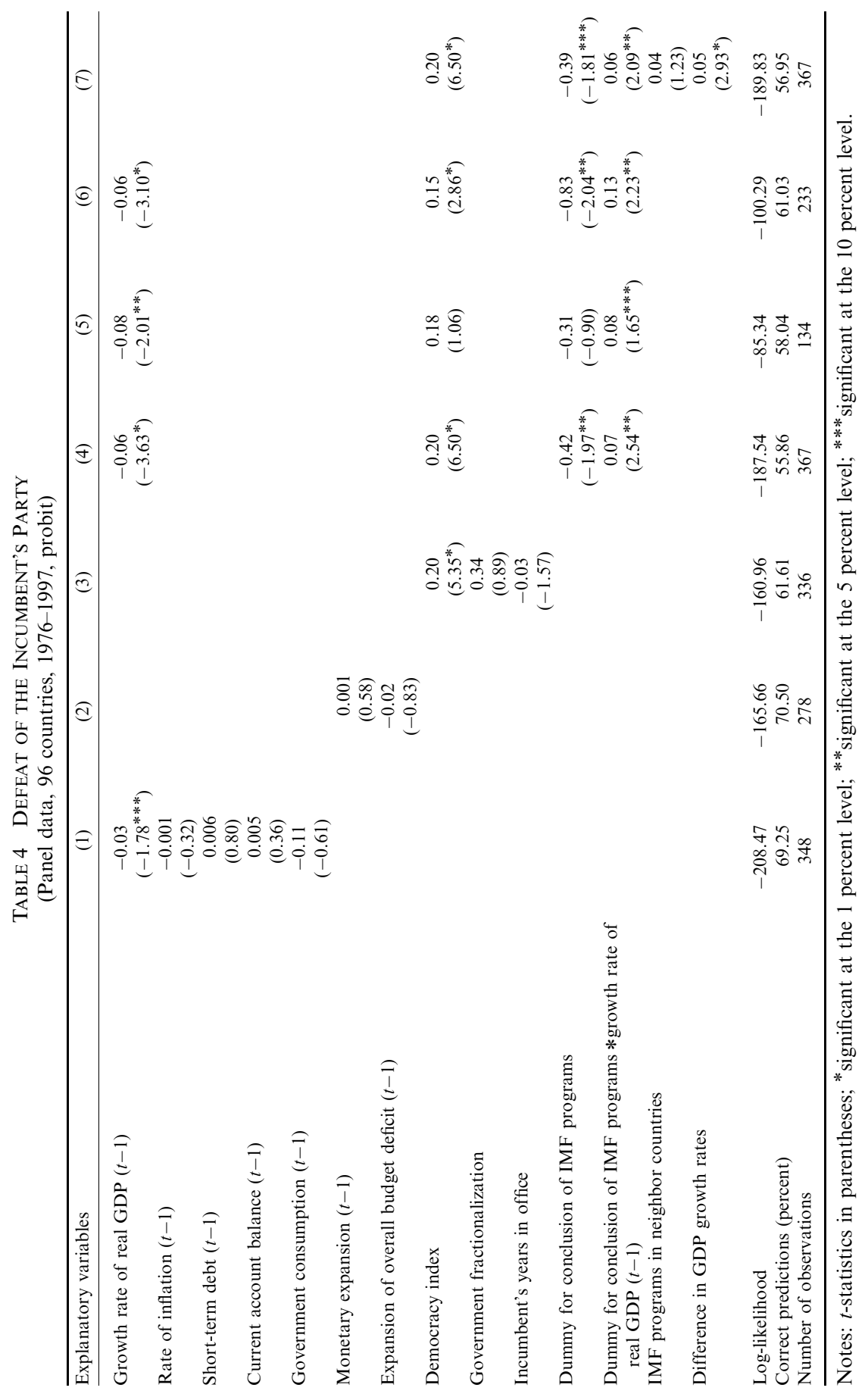


I also include the 10-scale Polity IV indicator of democracy. Obviously, the incumbent's electoral defeat should be more likely in more democratic countries. As the results show, only democracy is significantly associated with re-election and has the expected sign. Neither government fractionalization nor the time the incumbent has already been in office affect electoral outcomes significantly.

In the following, I keep only those covariates that have been significant in the previous regressions. To check for the influence of IMF programs on reelection probabilities, column 4 includes a dummy accounting for conclusions of IMF programs which are within 12 months prior to a national election. Since the model predicts a correlation between the state of the economy and the influence of program conclusions on re-election probabilities, I also include the interaction of program conclusions and (lagged) real GDP growth rates. As can be seen, the results are in line with the model: generally, conclusion of an IMF program increases re-election probabilities - but reduces them with higher growth rates. The program variables are significant at the 5 percent level both individually and jointly (prob $>0.015){ }^{17}$ The coefficients are economically relevant as well. Calculated at the mean of the independent variables (and assuming random effects equal to zero), conclusion of an IMF program increases the probability of getting re-elected by six percentage points. Increasing the growth rate of GDP by one percentage point leads to an increase in reelection probabilities by 0.5 percentage points and, when an arrangement has been concluded, a reduction in re-election probabilities by one percentage point through the interaction term. The overall effect of program conclusions on re-elections becomes negative with growth rates higher than 5.36 percent (the marginal effects are not reported in the table). With respect to the covariates, the results show that both democracy and real GDP growth retain their signs and are highly significant. The regression explains the dependent variable correctly almost 70 percent of the time.

Not all countries included in the sample are democracies - and the degree of democracy might influence the results. I therefore distinguish between true democracies (Polity IV index above six) and more autocratic regimes (index smaller than seven). The results are reported in columns 5 and 6 of Table 4. While both program variables keep their significance in the less democratic sample (column 6), the dummy for program conclusions no

\footnotetext{
${ }^{17}$ If the insignificant variables of the previous columns are included in the regression, the variables of interest are no longer significant. It is, however, inefficient to include those insignificant variables and their exclusion does not lead to omitted variable bias. Moreover, their inclusion reduces the number of observations by more than 100. If the IMF variables are included individually, their coefficients are insignificant as well. This is what one would expect: if the interaction is excluded, the dummy for conclusions takes over some of the positive impact of the interaction term on the dependent variable.
} 
longer influences re-election probabilities in true democracies (column 5). The interaction term, however, is significant at the 10 percent level.

Column 7 tests for the influence of benchmark countries on electoral outcomes. For this purpose, I calculated the average growth rate of real GDP in a certain region ("benchmark countries") excluding the growth rate of the respective country. I then used the difference between this average rate and a countries' growth rate instead of the growth rate itself. As an additional variable the change in a certain region's share of all IMF programs concluded relative to the previous year is also included.

I distinguish between the following six regions: Latin America and the Caribbean, South Asia, sub-Saharan Africa, Middle East and North Africa, Eastern Europe and Central Asia, as well as East Asia and the Pacific Area.

Although more IMF programs concluded in the same region indicate a higher probability of higher shocks, the coefficient of the additional variable is insignificant. To the contrary, if neighboring countries perform relatively better in terms of growth, re-election probabilities decrease significantly. All previous results remain.

As one problem with the analysis, election outcomes and program conclusions might be jointly determined. IMF programs are often concluded when the economy performs badly. There might thus be a selection problem and Fund arrangements could be endogenous. ${ }^{18}$ How to account for this endogeneity is, however, not obvious when both dependent and independent variables are binary. In spite of theoretical problems, I follow Angrist (2001) who suggested a linear 2 SLS procedure. ${ }^{19}$ In a first step, I replicate the analysis of Dreher (2003b) with the dummy for conclusions of IMF programs as the dependent variable. The second step is to instrument program conclusions and their interaction with GDP growth rates with the independent variables employed in the first step.

As previously discussed, whether demand for Fund credit rises prior to elections depends on the tradeoff between the interest rate subsidy provided by the IMF and its conditionality. Prior to elections, supply of IMF credit could differ from non-election time as well. The reasons are discussed at length in Dreher and Vaubel (2004). Most importantly, the IMF (or its major shareholders) might be supportive of the incumbent. Therefore, the Fund lends more freely - and without tough conditionality. ${ }^{20}$ On the other

\footnotetext{
${ }^{18}$ Vreeland (2003) provides an extensive discussion of the selection problem in the context of IMF programs.

${ }^{19}$ I therefore have to assume that re-election probabilities depend linearly on the independent variables, which is quite unrealistic. Moreover, the error term is heteroskedastic. It is nevertheless acceptable to present standard $t$-statistics (Wooldridge, 2000, p. 236). If a probit model is estimated instead, the estimator is inconsistent (Angrist, 2001).

${ }^{20}$ This has been the case, e.g., in Argentina prior to elections in 1985 and 1987 (Dreher, 2003b). Another example is the 1996 credit for Russia three months prior to presidential elections where the US and German governments induced the IMF to support President Yeltsin (Goricki, 1999, p. 223).
} 
hand, especially if election outcomes are uncertain, the Fund might only support a program receiving support from all possible future chief executives which makes conclusions less likely. ${ }^{21}$ The IMF may also want the incumbent to lose; then, he would either not lend prior to the election at all - or only with tough conditionality. ${ }^{22}$

To test for the influence of elections, I include the share of a year that falls within six months prior to and, respectively, after national elections. Supply and demand for IMF programs are also likely to be influenced by the potential borrowers' economic performance. As possible determinants, I employ the following (lagged) variables:

- the rate of monetary expansion;

- the change in the overall budget deficit relative to the previous year;

- general government consumption relative to GDP;

- the change in real GDP growth relative to the previous year;

- the share of foreign short-term debt in total foreign debt;

- the rate of inflation;

- the change in international reserves (in months of imports) relative to the previous year;

- the current account balance as a percent of GDP.

I also allow for two additional variables which are not, or hardly, affected by a country's policies but might influence program conclusions: a rise of LIBOR raises the interest rate subsidy, i.e. the demand for IMF credit. Moreover, it indicates a tightening of monetary conditions abroad which puts pressure on the exchange rate and increases the supply and demand for IMF credit. At the time of a quota review, the IMF might supply more credit because its staff hope to obtain a larger quota increase when resources are exhausted (Vaubel, 1991).

Table 5 reports the results. They show that only three regressors are significant at the 10 percent level at least: immediately prior to an election, fewer programs are concluded. While government consumption increases the probability of program conclusions one year later, higher international reserves lead to fewer program conclusions.

Finally, Table 6 reports results from 2SLS. As can be seen, the program variables are significant in both regressions at least at the 10 percent level. Their coefficients are comparable to the results of Table 4: the overall effect of an IMF program on re-election probabilities becomes negative with real GDP growth rates exceeding 5.09 percent. The difference between neighboring countries' growth rates stays significant at the 5 percent level; the influence of IMF programs in the same region is insignificant.

The next section sums up and draws conclusions.

${ }^{21}$ An example is Brazil prior to the 2002 election.

${ }^{22}$ This has been the case in Jamaica early in 1980 (Polanyi-Levitt, 1983, p. 252). 
TABle 5 Conclusion of IMF Programs

(Panel data, 54 countries, 1976-1997, probit)

\begin{tabular}{lc}
\hline Explanatory variables & \\
\hline Part of a year which is within six months prior to an election & -0.887 \\
& $\left(-2.24^{* *}\right)$ \\
Part of a year which is within six months after an election & 0.253 \\
& $(0.67)$ \\
Monetary expansion $(t-1)$ & 0.0001 \\
& $(0.20)$ \\
Expansion of overall budget deficit $(t-1)$ & -0.016 \\
Government consumption relative to GDP $(t-1)$ & $(-0.82)$ \\
& 0.028 \\
Change in real GDP growth $(t-1)$ & $\left(1.75^{* *}\right)$ \\
& -0.009 \\
Short-term debt relative to total debt $(t-1)$ & $(-0.76)$ \\
& 0.003 \\
Rate of inflation $(t-1)$ & $(0.33)$ \\
Change of international reserves in months of imports $(t-1)$ & -0.0001 \\
Current account balance $(t-1)$ & $(-0.36)$ \\
Quota review & -0.14 \\
LIBOR $(t-1)$ & $\left(-3.63^{*}\right)$ \\
& -0.002 \\
Log-likelihood & $(-0.22)$ \\
Norrect predictions (percent) & -0.23 \\
\hline
\end{tabular}

Notes: $t$-statistics in parentheses; ${ }^{*}$ significant at the 1 percent level; ${ }^{* *}$ significant at the 5 percent level; ${ }^{* * *}$ significant at the 10 percent level.

\section{SUMMARY AND IMPLICATIONS FOR REFORM}

The paper explains two puzzling stylized facts. On the one hand, prior to national elections fewer IMF programs are concluded. On the other, governments who do conclude an arrangement do not generally seem to decrease their re-election probability. The model presented can explain this puzzle: if the economy performs badly, both competent and incompetent politicians turn to the Fund. Since voters thus cannot interpret Fund involvement as a signal of incompetence, they re-elect their government. With an economy performing moderately, however, competent politicians do not have to turn to the Fund. They therefore signal their competence by borrowing from the market or other countries and get re-elected. Incompetent politicians lose the election (and conclude an IMF arrangement). 
TABle 6 Defeat of the InCumbent's Party

(Panel data, 54 countries, 1976-1997, 2SLS)

\begin{tabular}{lcc}
\hline Explanatory variables & $(1)$ & $(2)$ \\
\hline Growth rate of real GDP $(t-1)$ & -0.031 & \\
& $\left(-2.39^{* *}\right)$ & 0.063 \\
Democracy index & 0.061 & $\left(5.66^{*}\right)$ \\
& $\left(5.67^{*}\right)$ & -0.674 \\
Dummy for conclusion of IMF programs & -0.692 & $\left(-1.94^{* * *}\right)$ \\
& $\left(-1.96^{* *}\right)$ & 0.136 \\
Dummy for conclusion of IMF programs* & 0.136 & $\left(1.84^{* * *}\right)$ \\
$\quad$ growth rate of real GDP $(t-1)$ & $\left(1.81^{* * *}\right)$ & 0.026 \\
IMF programs in neighbor countries & & $(1.48)$ \\
& & 0.029 \\
Difference in GDP growth rates & & $\left(2.31^{* *}\right)$ \\
& & 0.17 \\
$R^{2}$ & 0.18 & 191 \\
Number of observations & 191 & \\
\hline
\end{tabular}

Notes: $t$-statistics in parentheses; ${ }^{*}$ significant at the 1 percent level; ${ }^{* *}$ significant at the 5 percent level; ${ }^{* * *}$ significant at the 10 percent level.

Estimation is by two-stage least squares. IMF program variables are instrumented with all independent variables of Tables 4 and 5 .

The empirical part of the paper has shown that governments who conclude IMF arrangements within 12 months prior to an election generally increase their re-election probability. This increased probability of getting re-elected after program conclusions decreases, however, with rising GDP growth. The likelihood of losing an election is also higher when other countries in the same region experience higher GDP growth. Re-election is, moreover, positively influenced by the absolute level of GDP growth and negatively by the degree of democracy.

Even though the model concentrated on specific aspects - and necessarily had to omit many facets - it has been constructed to reproduce the Fund's real-world behavior. This behavior has frequently been criticized. I focus on two points. First, the Fund subsidizes its lending in order to increase demand for its resources (Vaubel, 1983). This induces governments to borrow from the Fund even though they have access to private capital. Their behavior indicates that the interest rate subsidy outweighs the costs imposed by Fund conditionality - probably because this conditionality is ineffective. It has been pointed out in several studies that compliance with conditionality is generally low (Killick, 1995; Mussa and Savastano, 2000). As has been shown by Dreher (2003a), compliance is even lower prior to elections. The Fund should therefore raise the opportunity cost of borrowing from the institution. The interest rate subsidy should be eliminated (Vaubel, 1991). Indeed, as recommended by the IFIAC (2000), it should be replaced by a penalty so that the financial institution becomes a lender of last resort. 
The model also suggests that the IMF generally lends to incompetent governments. This is my second point. Many countries receive loans from the Fund on a continuous basis. Although many arrangements break down, the Fund immediately starts to negotiate a new program after the breakdown. Past compliance does not seem to be important for future credits (Bird, 2002; Dreher, 2003a). The only prerequisite for Fund money seems to be (alleged) acceptance of certain conditions. It has been argued by Dollar and Svensson (2000), however, that imposing conditionality on reluctant governments is doomed to failure. Instead of trying to impose such conditionality, the IMF should only support countries with "good" policies. Most importantly, development agencies have to identify and support reformminded governments. This implies that the Fund should not lend to "incompetent" governments at all. If the Fund's "seal of approval" would really signal "good" policies conducted by "competent" governments, voters could rely on that signal and re-elect politicians who conclude an arrangement.

APPENDIX A. DEFINITIONS AND DATA SOURCES

\begin{tabular}{|c|c|c|}
\hline Variable & Source & Definition \\
\hline $\begin{array}{l}\text { Defeat of } \\
\text { the incumbent }\end{array}$ & $\begin{array}{l}\text { Beck et al. } \\
\text { (2001) }\end{array}$ & $\begin{array}{l}\text { Dummy which takes the value of } \\
\text { one for years in which the chief } \\
\text { executive's party lost a national } \\
\text { election and zero otherwise. }\end{array}$ \\
\hline $\begin{array}{l}\text { Growth rate } \\
\text { of real GDP }\end{array}$ & IBRD (2000) & $\begin{array}{l}\text { Annual percentage growth rate of } \\
\text { GDP at market prices based on } \\
\text { constant local currency. Aggre- } \\
\text { gates are based on constant } 1995 \\
\text { US dollars. }\end{array}$ \\
\hline Rate of inflation & IBRD (2000) & $\begin{array}{l}\text { Measured by the consumer price } \\
\text { index. The Laspeyres formula is } \\
\text { generally used. }\end{array}$ \\
\hline $\begin{array}{l}\text { Short-term debt } \\
\text { (in percent of } \\
\text { total external debt) }\end{array}$ & IBRD (2000) & $\begin{array}{l}\text { Short-term debt includes all debt } \\
\text { having an original maturity of one } \\
\text { year or less and interest in arrears on } \\
\text { long-term debt. }\end{array}$ \\
\hline $\begin{array}{l}\text { Current account } \\
\text { balance (as percent } \\
\text { of GDP) }\end{array}$ & IBRD (2000) & $\begin{array}{l}\text { Current account balance is the sum } \\
\text { of net exports of goods, services, net } \\
\text { income, and net current transfers. }\end{array}$ \\
\hline $\begin{array}{l}\text { Government } \\
\text { consumption } \\
\text { (as percent of } \\
\text { GDP) }\end{array}$ & IBRD (2000) & $\begin{array}{l}\text { All current spending for purchases } \\
\text { of goods and services (including } \\
\text { wages and salaries). It also } \\
\text { includes most expenditures on } \\
\text { national defense and security, } \\
\text { but excludes government } \\
\text { military expenditures that are } \\
\text { part of government capital } \\
\text { formation. }\end{array}$ \\
\hline
\end{tabular}


APPENDIX A Continued

\begin{tabular}{|c|c|c|}
\hline Variable & Source & Definition \\
\hline Monetary expansion & IBRD (2000) & $\begin{array}{l}\text { Average annual growth rate in } \\
\text { money and quasi-money (M2). }\end{array}$ \\
\hline $\begin{array}{l}\text { Expansion of overall } \\
\text { budget deficit }\end{array}$ & IBRD (2000) & $\begin{array}{l}\text { Change in the change of direct } \\
\text { government fixed-term contractual } \\
\text { obligations to others. It includes } \\
\text { domestic debt and foreign debt. }\end{array}$ \\
\hline Democracy index & $\begin{array}{l}\text { Marshall and } \\
\text { Jaggers (2000) }\end{array}$ & $\begin{array}{l}\text { Measures the general openness of } \\
\text { political institutions on a } 0-10 \\
\text { scale }(0=\text { low; } 10=\text { high })\end{array}$ \\
\hline $\begin{array}{l}\text { Government } \\
\text { fractionalization }\end{array}$ & $\begin{array}{l}\text { Beck et al. } \\
\quad(2001)\end{array}$ & $\begin{array}{l}\text { Measures the probability that any } \\
\text { two government legislators } \\
\text { drawn at random belong to the } \\
\text { same party. }\end{array}$ \\
\hline $\begin{array}{l}\text { Incumbent's } \\
\text { years in office }\end{array}$ & $\begin{array}{l}\text { Beck et al. } \\
\quad(2001)\end{array}$ & $\begin{array}{l}\text { Measures the number of years the } \\
\text { chief executive's party has been } \\
\text { in office. }\end{array}$ \\
\hline $\begin{array}{l}\text { Dummy for conclu- } \\
\text { sion of IMF } \\
\text { programs }\end{array}$ & $\begin{array}{l}\text { IMF Annual } \\
\quad \text { Report } \\
\text { (various } \\
\text { years) }\end{array}$ & $\begin{array}{l}\text { The dummy takes the value of one } \\
\text { if an IMF program is concluded } \\
\text { within } 12 \text { months prior to a } \\
\text { national (executive or legislative) } \\
\text { election. }\end{array}$ \\
\hline $\begin{array}{l}\text { IMF programs in } \\
\text { neighbor countries }\end{array}$ & $\begin{array}{l}\text { IMF Annual } \\
\quad \text { Report } \\
\text { (various } \\
\text { years) }\end{array}$ & $\begin{array}{l}\text { The number of IMF programs } \\
\text { concluded in the same region } \\
\text { ("benchmark countries") relative } \\
\text { to all programs concluded in the } \\
\text { same year. }\end{array}$ \\
\hline $\begin{array}{l}\text { Difference in real } \\
\text { GDP growth rates }\end{array}$ & IBRD (2000) & $\begin{array}{l}\text { The average growth rate of real } \\
\text { GDP in a certain region (exclud- } \\
\text { ing the growth rate of the } \\
\text { respective country) less the } \\
\text { respective country's growth rate. }\end{array}$ \\
\hline Election years & $\begin{array}{l}\text { Beck et al. } \\
\quad(2001)\end{array}$ & \\
\hline International reserves & IBRD (2000) & $\begin{array}{l}\text { Comprise holdings of monetary } \\
\text { gold, SDRs, the reserve position of } \\
\text { members in the IMF, and } \\
\text { holdings of foreign exchange } \\
\text { under the control of monetary } \\
\text { authorities. Data are expressed } \\
\text { in terms of the number of } \\
\text { months of imports of goods and } \\
\text { services which could be paid for. }\end{array}$ \\
\hline Quota review & $\begin{array}{l}\text { IMF Annual } \\
\quad \text { Report } \\
\quad \text { (various years) }\end{array}$ & $\begin{array}{l}\text { Dummy which takes the value of one } \\
\text { for years in which IMF quotas were } \\
\text { under review and zero otherwise. }\end{array}$ \\
\hline LIBOR & IBRD $(2000)$ & $\begin{array}{l}\text { The average three-month London } \\
\text { interbank offer rate on US dollar } \\
\text { deposits. }\end{array}$ \\
\hline
\end{tabular}


APPENDIX B. DESCRIPTIVE STATISTICS (ESTIMATION SAMPLE)

\begin{tabular}{lcc}
\hline Variable & Mean & $\begin{array}{c}\text { Std. dev. } \\
\text { (overall) }\end{array}$ \\
\hline Defeat of the incumbent & 0.33 & 0.47 \\
Growth rate of real GDP & 1.986 & 6.39 \\
Rate of inflation & 142.588 & 679.42 \\
Short-term debt (in total debt) & 13.09 & 11.70 \\
Current account balance (as percent of GDP) & -4.609 & 6.44 \\
Government consumption (as percent of GDP) & 14.457 & 6.22 \\
Monetary expansion & 78.670 & 310.67 \\
Expansion of overall budget deficit & -0.123 & 4.61 \\
Democracy index & 3.902 & 3.82 \\
Government fractionalization & 0.127 & 0.245 \\
Incumbent's years in office & 8.369 & 7.52 \\
Dummy for conclusion of IMF programs & 0.226 & 0.42 \\
IMF programs in neighbor countries & 0.586 & 2.90 \\
Difference in GDP growth rates & 0.022 & 6.28 \\
Part of year which is within six months prior & 0.132 & 0.20 \\
$\quad$ to an election & & \\
Part of year which is within six months after & 0.130 & 0.20 \\
$\quad$ an election & & \\
Change in real GDP growth & 0.086 & 5.49 \\
Change in international reserves & 3.611 & 2.61 \\
Quota review & 0.124 & 0.33 \\
LIBOR & 7.869 & 3.30 \\
\hline
\end{tabular}

APPENDIX C. COUNTRIES INCLUDED IN THE ANALYSIS

\begin{tabular}{lclc}
\hline Country & $\begin{array}{c}\text { First year } \\
\text { of inclusion }\end{array}$ & Country & $\begin{array}{c}\text { First year } \\
\text { of inclusion }\end{array}$ \\
\hline Albania & 1991 & Chad & 1990 \\
Algeria & 1976 & Chile & 1989 \\
Argentina & 1983 & Colombia & 1978 \\
Armenia & 1995 & Comoros & 1984 \\
Azerbaijan & 1992 & Costa Rica & 1978 \\
Bangladesh & 1977 & Croatia & 1995 \\
Benin & 1979 & Djibouti & 1993 \\
Bolivia & 1985 & Dominican Rep. & 1978 \\
Brazil & 1982 & Ecuador & 1979 \\
Bulgaria & 1991 & Egypt & 1976 \\
Burkina Faso & 1978 & El Salvador & 1977 \\
Burundi & 1982 & Equatorial Guinea & 1988 \\
Cambodia & 1993 & Estonia & 1996 \\
Cameroon & 1980 & Ethiopia & 1995 \\
Central African Rep. & 1986 & Gabon & 1979 \\
\hline
\end{tabular}




\begin{tabular}{|c|c|c|c|}
\hline Country & $\begin{array}{l}\text { First year } \\
\text { of inclusion }\end{array}$ & Country & $\begin{array}{l}\text { First year } \\
\text { of inclusion }\end{array}$ \\
\hline Gambia, The & 1977 & Niger & 1989 \\
\hline Georgia & 1995 & Panama & 1978 \\
\hline Ghana & 1979 & Pakistan & 1977 \\
\hline Guinea & 1993 & Paraguay & 1978 \\
\hline Guinea-Bissau & 1994 & Peru & 1980 \\
\hline Guyana & 1980 & Philippines & 1978 \\
\hline Haiti & 1979 & Portugal & 1976 \\
\hline Honduras & 1985 & Romania & 1985 \\
\hline Hungary & 1980 & Rwanda & 1978 \\
\hline India & 1977 & Senegal & 1978 \\
\hline Indonesia & 1977 & Sierra Leone & 1976 \\
\hline Israel & 1976 & Singapore & 1976 \\
\hline Jamaica & 1976 & Slovak Rep. & 1994 \\
\hline Jordan & 1989 & Slovenia & 1992 \\
\hline Kazakhstan & 1994 & South Africa & 1977 \\
\hline Kenya & 1979 & Sri Lanka & 1977 \\
\hline Lao PDR & 1992 & Sudan & 1977 \\
\hline Latvia & 1993 & Tajikistan & 1994 \\
\hline Lesotho & 1993 & Tanzania & 1990 \\
\hline Lithuania & 1992 & Thailand & 1979 \\
\hline Macedonia & 1994 & Togo & 1979 \\
\hline Madagascar & 1977 & Trinidad and Tobago & 1976 \\
\hline Malawi & 1976 & Tunisia & 1981 \\
\hline Malaysia & 1978 & Turkey & 1977 \\
\hline Mali & 1979 & Uganda & 1989 \\
\hline Mauritania & 1976 & Ukraine & 1994 \\
\hline Mexico & 1976 & Uruguay & 1984 \\
\hline Moldova & 1994 & Uzbekistan & 1994 \\
\hline Mongolia & 1986 & Venezuela & 1978 \\
\hline Morocco & 1977 & Vietnam & 1987 \\
\hline Mozambique & 1986 & Yemen, Rep. & 1993 \\
\hline Nepal & 1981 & Zambia & 1978 \\
\hline Nicaragua & 1984 & Zimbabwe & 1979 \\
\hline
\end{tabular}

\section{ACKNOWLEDGMENTS}

The author is grateful for many helpful comments by Bernhard Boockmann, Allan Drazen, Roland Vaubel, Eduard Wagner, and the participants of the Annual Meeting of the European Public Choice Society, April 26-28, 2003. The valuable comments of two anonymous referees are also gratefully acknowledged.

AXEL DREHER

University of Mannheim, Germany 
Angrist, J. D., 2001, Estimation of limited dependent variable models with dummy endogenous regressors: simple strategies for empirical practice. Journal of Business and Economic Statistics 19(1), 2-16.

Barro, R. J. and J.-W. Lee, 2001, IMF-programs: who is chosen and what are the effects? Paper presented at the IMF Annual Research Conference, November 29 30, 2001.

Beck, T. et al., 2001, New tools in comparative political economy: the database of political institutions. World Bank Economic Review 15(1), 165-176.

Besley, T. and A. Case, 1995, Incumbent behaviour: vote-seeking, tax-setting, and yardstick competition. American Economic Review 85(1), 25-45.

Bird, G., 2002, Conditionality and ownership: how to improve the implementation of IMF programmes. Surrey Centre for International Economic Studies.

—_ and D. Rowlands, 2000, IMF lending: how is it affected by economic, political and institutional factors? Mimeo.

Boockmann, B. and A. Dreher, 2003, The contribution of the IMF and the World Bank to economic freedom. European Journal of Political Economy 19(3), 633649.

Collier, P., 1997, The failure of conditionality, in: C. Gwin and J. M. Nelson, eds., Perspectives on Aid and Development (Overseas Development Council, Washington, DC) 51-77.

Dicks-Mireaux, L., M. Mecagni, and S. Schadler, 2000, Evaluating the effect of IMF lending to low income countries. Journal of Development Economics 61, 495-526.

Dollar, D. and J. Svensson, 2000, What explains the success or failure of structural adjustment programs? Economic Journal 110, 894-917.

Dreher, A., 2003a, The influence of elections on IMF program interruptions. Journal of Development Studies 39(6), 101-120.

—_, 2003b, Die Kreditvergabe von IWF und Weltbank: Ursachen und Wirkungen aus politisch-ökonomischer Sicht (Wissenschaftlicher Verlag Berlin, Berlin).

—_, 2003c, A public choice perspective of IMF and World Bank lending and conditionality. Public Choice, forthcoming.

— and R. Vaubel, 2004, Do IMF and IBRD cause moral hazard and political business cycles? Evidence from panel data. Open Economies Review 15(1), 5-22.

Ergin, E., 1999, Determinants and consequences of International Monetary Fund programs. PhD dissertation, Stanford University.

Goricki, C., 1999, Marktwirtschaftliche Reformsteuerung - Die Rolle von IWF und Weltbank in Mittelosteuropa nach 1990 (Verlag Fakultas, Singapur).

IBRD (International Bank for Reconstruction and Development), 2000, World Development Indicators. CD-ROM, Washington, DC.

IFIAC (International Financial Institutions Advisory Commission), 2000, Chairman: A. Meltzer (Report, http://phantom-x.gsia.cmu.edu/IFIAC/USMRPTDV. html) September 1, 2000.

Killick, T., 1995, IMF Programmes in Developing Countries - Design and Impact (Routledge, London).

- M. Malik, and M. Manuel, 1992, What can we know about the effects of IMF programmes? The World Economy 15(5), 575-597.

Marshall, M. G. and K. Jaggers, 2000, Polity IV Project, Political Regime Characteristics and Transitions, 1800-1999.

Mussa, M. and M. Savastano, 2000, The IMF approach to economic stabilization, in: B. S. Bernanke and J. J. Rotemberg, eds., NBER Macroeconomics Annual 1999 (MIT Press, Cambridge, MA) 79-122. 
Nelson, J. M., 1992, Poverty, equity, and the politics of adjustment, in: S. Haggard and R. R. Kaufman, eds., The Politics of Economic Adjustment: International Constraints, Distributive Conflicts, and the State (Princeton University Press, Princeton, NJ) 221-269.

Persson, T. and G. Tabellini, 2000, Political Economics, Explaining Economic Policy (MIT Press, Cambridge, MA).

Polanyi-Levitt, K., 1983, Jamaica: Manley's defeat - whose responsibility?, in: J. Torrie, ed., Banking on Poverty - The Global Impact of the IMF \& World Bank (Toronto, Canada) 241-260.

Przeworski, A. and J. Vreeland, 2000, The effect of IMF programs on economic growth. Journal of Development Economics 62, 385-421.

Rogoff, K., 1990, Equilibrium political budget cycles. American Economic Review 80(1), 21-36.

Schadler, S., F. Rozwadowski, S. Tiwari, and D. O. Robinson, 1993, Economic adjustment in low-income countries: experience under the enhanced structural adjustment facility. IMF Occasional Paper No. 106, Washington, DC.

Schuknecht, L., 2000, Fiscal policy cycles and public expenditure in developing countries. Public Choice 102, 115-130.

Vaubel, R., 1983, The moral hazard of IMF lending, in: A. H. Meltzer, ed., International Lending and the International Monetary Fund: A Conference in Memory of Wilson E. Schmidt (Heritage Foundation, Washington, DC) 65-79.

_- 1991, The political economy of the International Monetary Fund: a public choice approach, in: R. Vaubel and T. D. Willett, eds., The Political Economy of International Organizations (Westview Press, Boulder, CO) 205-245.

Vreeland, J. R., 1999, The IMF: Lender of Last Resort or Scapegoat? (Yale University Press, New Haven, CT).

—_, 2002, The effect of IMF programs on labour. World Development 30, 121139.

, 2003, The IMF and Economic Development (Cambridge University Press, New York).

Wooldridge, J. M., 2000, Introductory Economics - A Modern Approach (SouthWestern College Publishing, Thomson Learning). 